\title{
The feeding of the elderly in their own homes: defining the need
}

\author{
By Joyce Grant, Senior Medical Officer (Geriatrics), \\ City and County of Newcastle-upon-Tyne
}

\section{Factors related to malnutrition in old age}

There is usually a decrease in the intake of all nutrients by the late seventies. What has been demonstrated, however, is that there is a close relationship between diet and health. Nearly all subjects in a survey (Exton-Smith \& Stanton, 1965) whose diet was better than average, as assessed by the proportion of calories contributed by protein, enjoyed better than average health; subjects on a poor diet had worse than average health. This is not to say that diet must have affected health; the reverse might equally be true. Undoubtedly nutrition in old age is related to mental and social factors as well as physical health. It is not known whether this is due to a pathological change in appetite, a reduction in physical activity, a change in body weight and composition, or a decrease in muscular efficiency (Durnin, 1964).

Overfeeding is rarely a problem in old age and obesity is associated with a higher mortality, particularly in males.

It is unlikely that there is massive malnutrition among those receiving retirement pensions, but it is clear that about a quarter of a million of their households barely attain the nutrition levels recommended by the British Medical Association, particularly as regards protein, calcium and iron (Ministry of Agriculture, Fisheries and Food: National Food Survey Committee, ig66). Loneliness, eating alone, poor cooking facilities and financial worry lead to depression, apathy and lack of initiative. The food intake of married couples is found to be far superior to that of a single person living alone and whenever a pensioner is able to eat with a family and share a communal life for part of a day the food intake is increased (Morris, 1959). However, some persons who have lived alone for many years may have learned how to cater for themselves adequately when younger. Nutrition is improved with admission to any form of care once eating in company is resumed (Read, Gough, Pardoe \& Nicholas, 1965). For people who have difficulty in getting about, shortage of money is probably of less importance than the effort required to shop and cook. Mental confusion may also be expected to lead to considerable dietary deficiency (ExtonSmith \& Stanton, 1965). In other words the groups at special risk are the physically handicapped or mentally impaired who are socially isolated and the recently bereaved.

\section{Diagnosis of malnutrition}

Laboratory tests are of little help in diagnosing malnutrition since they are technically difficult, expensive and not always available. Various authors have suggested that socio-medical breakdowns necessitating the admission of old people to geriatric wards and residential homes are associated with deficiency in vitamins $\mathrm{C}$ and $\mathrm{B}$ and of folic acid. A survey of I 8 geriatric hospital admissions showed that $58 \%$ were 
deficient in vitamin $\mathrm{C}, 40 \%$ in thiamine and $24 \%$ in both (Griffiths, Brocklehurst, Scott, Marks \& Blackley, 1967). Of fifty-one new entrants to a residential home, $80 \%$ were deficient in serum folate, and low levels were found in $67 \%$ (Read et al. $1965)$.

However, the most practical method is to make a careful assessment of the diet, combined with the size and weight of the subject, with particular regard to weight loss. Mental apathy and kyphosis may also be caused by malnutrition.

\section{Evidence for expansion of services}

It is reported that $10 \%$ of people over $6_{5}$ have difficulty in preparing a hot meal (Townsend \& Wedderburn, I965). Of this group the majority are cared for within the family or by friends; only $4 \%$ obtain help from social services and $10 \%$ receive no help at all. This means that no more than $0.5 \%$ of the total elderly population receives help with cooking meals from the social services. These authors also show that only $1 \cdot 0 \%$ of all elderly persons receive meals-on-wheels at least once a week. Exton-Smith \& Stanton (I965) have suggested that for the maintenance of proper nutrition four or five meals a week are needed. In fact, only about a third of the recipients of meals-on-wheels have this number; very few receive a weekend meal. What is more, nearly six times as many people as are receiving meals-on-wheels would like to have them, and the majority of these live alone and are incapacitated and are thus not able to get out for a meal.

Isolated elderly pensioners whose health is failing and who also are on a limited income can only afford a monotonous diet. They also frequently lack the energy to shop for and carry a more varied one, so that bulky fruit and vegetables tend to be omitted. Although it is expected that almost $f_{\mathrm{I}} \mathrm{r}$ ros. od. out of the weekly pension of $f 4$. Os. od. should be spent on food, of the $10 \%$ who experience difficulty in cooking and do not receive or refuse help, there are undoubtedly some who only spend about half this sum. There is not a great deal of detailed information about the dietary need in old age but it is certain that adequate roughage and fluid intake are vital. Constipation leading to faecal impaction is a common problem. ExtonSmith \& Stanton indicate that protein content in relation to carbohydrate should be high and iron and calcium intake tend to become inadequate as the eighth decade approaches. Difficulties in obtaining, eating and indeed dislike of fresh fruit and salads are reflected in low vitamin $\mathrm{C}$ intake. Diets prepared in large residential homes and hospitals are invariably low in vitamins $\mathrm{C}, \mathrm{B}$ and $\mathrm{K}$ (Andrews, Brook \& Allen, 1966). 'There may, therefore, be a case for providing protein, milk and vitamin supplements for vulnerable groups which may need to be delivered to their homes, rather than extra financial benefits.

Further research is needed into the relationship between malnutrition, laboratory investigations and some simple measurement such as the Ponderal Index (that is the height divided by the cube root of the weight). Such criteria could perhaps be related to health or disease, for a defective diet almost certainly relates to ill-healthusing the World Health Organization definition of health. Nutrition, however, is 
but one aspect of a multitude of problems of health and welfare in old age, and dramatic improvement in the health of some old pcople a few weeks after admission to a residential home raises the question that their admission might have been avoided had they been better fed in their own homes; this would certainly seem to have advantages also in economic terms.

\title{
REFERENCES
}

Andrews, J., Brook, M. \& Allen, M. A. (1966). Geront. clin. 8, no. 5, p. 257 .

Durnin, J. V. G. A. (1964). In Current Achievements in Geriatrics. Vol. 5, p. 4I. [W. F. Anderson and B. Isaacs, editors.] London: Cassell.

Exton-Smith, A. N. \& Stanton, B. R. (I965). Report of an Investigation into the Dietary of Elderly People Living Alone. King Edward's Hospital Fund for I.ondon.

Griffiths, L. L., Brocklehurst, J. C., Scott, D. L., Marks, J. \& Blackley, J. (1967). Geront. clin. 9, no. I, p. I.

Ministry of Agriculture, Fisheries and Food: National Food Survey Committee. (1966). Damestic Food Consumption and Expenditure, 1964. London: H.M. Stationery Office.

Morris, G. K. (1959). Nutrition, Iond. 13, I25.

Read, A. E. A., Gough, K. R., Pardoe, J. L. \& Nicholas, A. (1965). Br. med. J. ii, 843 .

Townsend, P. \& Wedderburn, D. (1965). The Aged in the Welfare State (The Interim Report of a Survey of Persons aged $6_{5}$ and over in Britain, $x_{962}$ and 1963 ). London: Bell.

\section{Feeding the elderly in their own homes: meeting the need}

\author{
By R. C. M. Pearson, Medical Officer of Health, \\ City and County of Nercastle-upon-Tyne
}

\section{Housing}

It has been assumed that provision of the basic financial needs of the social isolates, the housebound and the mildly mentally disturbed, especially those of them who live alone and present the real nutritional problem, is beyond the scope of this paper. So many of them live in the twilight areas with poor cooking facilities, but when rehoused for medical reasons or owing to slum clearance, they need very careful consideration and skilled guidance so that they will have a relative, friend or sympathetic neighbour reasonably near at hand. No social service can ever hope to meet all their needs as they get older. There is a growing opinion that when given this type of 'housing management' this group makes less demands on residential care. As a result, adequate warmth at home leads to greater mobility and better appetite with all-round improvement in health and less demand on the other services.

Groups of outward-looking flatlets and bungalows in reasonable proximity to residential homes enable the frail elderly to have a midday meal in the dining room. The staff of the home with their own warden can together maintain a friendly eye on their total food intake. Transport may be necessary.

\section{The Home Help Service}

The greatest contribution to the prevention of malnutrition amongst the isolated elderly is the Home Help Service, but this service is limited by finance and recruit- 